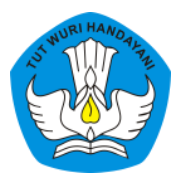

Page: $409-434$

\title{
Pengembangan Game Edukasi Android Mat Croco Berorientasi pada Penalaran Matematika
}

\author{
Hadi Sutrisno \\ Sekolah Menengah Pertama Negeri 1 Tanahmerah Bangkalan \\ Email: math.united@gmail.com
}

Published: Jul 30, 2020

Article Url: https:/ / ojsdikdas.kemdikbud.go.id/index.php/didaktika/article/view/134

\begin{abstract}
In 2017, 36\% of 43.7 million gamers in Indonesia were students. This development research aims to produce android educational game Mat Croco has good quality (valid, practical and effective). Type of this research is a research development (ADDIE model). The results of the Mat Croco validity test by two experts were stated to have a good validity. It shown media validity score 36.5 and validity score about math reasoning is also 36.5. The results of the practicality analysis by two mathematics teachers and two students showed that the Mat Croco game had excellent practicality. The average score of practicality by 37 teachers and practicality scores of students 36. The results of the analysis effectiveness test game Mat Croco effectively oriented students' mathematical reasoning. Descriptive analysis has increased the average value of mathematical reasoning (pretest $=28.4$ and posttest $=$ 84.4) and the percentage of completeness (pretest $=0 \%$ and posttest $=75.9 \%$ ). Paired Samples Test concluded that the Mat Croco game was effectively oriented towards mathematical reasoning $(|t|(25,200)>t$ table $(t 0.025 ; 28=2.368)$ and sig. $(0,000)<0.0025)$. The results of the analysis show that the Mat Croco has good quality (valid, practical and effective) and is worth applying in the mathematics learning of sequence and series mathematics.
\end{abstract}

Keywords: Android Education Game Mat Croco, Mathematical Reasoning 


\begin{abstract}
Abstrak
Pada tahun 2017, 36\% dari 43,7 juta pemain game di Indonesia adalah anak usia sekolah. Penelitian pengembangan ini bertujuan menghasilkan game edukasi android Mat Croco yang memiliki kualitas baik (valid, praktis dan efektif). Jenis penelitian ini merupakan penelitian pengembangan model ADDIE. Hasil analisis uji kevalidan game Mat Croco oleh dua ahli dinyatakan memiliki kevalidan yang baik. Hal ini ditunjukkan dari skor kevalidan media pembelajaran 36,5 dan skor kevalidan soal penalaran matematika juga 36,5. Hasil analisis kepraktisan oleh dua guru matematika dan dua siswa menunjukkan bahwa game Mat Croco memiliki kepraktisan yang sangat baik. Rata-rata skor kepraktisan oleh guru 37 dan skor kepraktisan dari siswa 36. Hasil analisis uji keefektifan game Mat Croco efektif berorientasi penalaran matematika siswa. Analisis deskriptif mengalami peningkatan ratarata nilai penalaran matematika (pretes $=28,4$ dan postes $=84,4$ ) dan persentase ketuntasan (pretes $=0 \%$ dan postes $=75,9 \%$ ). Paired Samples Test menyimpulkan bahwa game Mat Croco efektifberorientasi penalaran matematika $(|t|(25,200)>t$ tabel $(t 0,025 ; 28=2,368)$ dan sig. $(0,000)<0,0025)$. Hasil analisis menunjukkan bahwa game edukasi android Mat Croco memiliki kualitas yang baik (valid, praktis dan efektif) dan layak diaplikasikan dalam pembelajaran matematika materi barisan dan deret.
\end{abstract}

Keywords: Game Edukasi Android Mat Croco, Penalaran Matematika

\title{
A. Pendahuluan
}

Revolusi industri 4.0 memasuki dunia pendidikan di Indonesia. Hal ini dibuktikan dengan banyaknya kegiatan dunia pendidikan di Indonesia yang telah mengintegrasikan teknologi informasi ke dalamnya. Ujian nasional telah menggunakan ujian berbasis komputer. Pendidikan Profesi Guru (PPG) diawali dengan sistem pendidikan daring. Seleksi kegiatan guru yang dilaksanakan oleh Kemendikbud banyak yang dilaksanakan secara online, serta masih banyak integrasi teknologi informasi ke dalam dunia pendidikan Indonesia. Revolusi industri 4.0 di dunia pendidikan Indonesia bertujuan untuk meningkatkan kualitas pendidikan di Indonesia.

Revolusi industri 4.0 juga melanda anak usia sekolah. Hampir semua anak usia sekolah telah memasuki dunia internet. Anak SD hingga 
SMA banyak yang telah memiliki akun sosial media seperti facebook, instagram, twitter, youtube dan sosial media lain. Selain sosial media ada juga fenomena ruang guru yang bisa diakses anak usia sekolah sebagai media belajar online bagi siswa sekolah. Akhir-akhir ini yang banyak dibahas adalah banyaknya game android online yang beredar sebagai dampak revolusi industri 4.0. Game viral dan banyak dimainkan oleh siswa antara lain angry bird, flapy bird, Pokemon Go, CoC, Minecraft, Mobile Legend dan PUGB.

Siswa di Indonesia banyak yang memainkan game android. Menurut data Newzoo (2017: 1) data gamer di Indonesia seperti gambar 1.

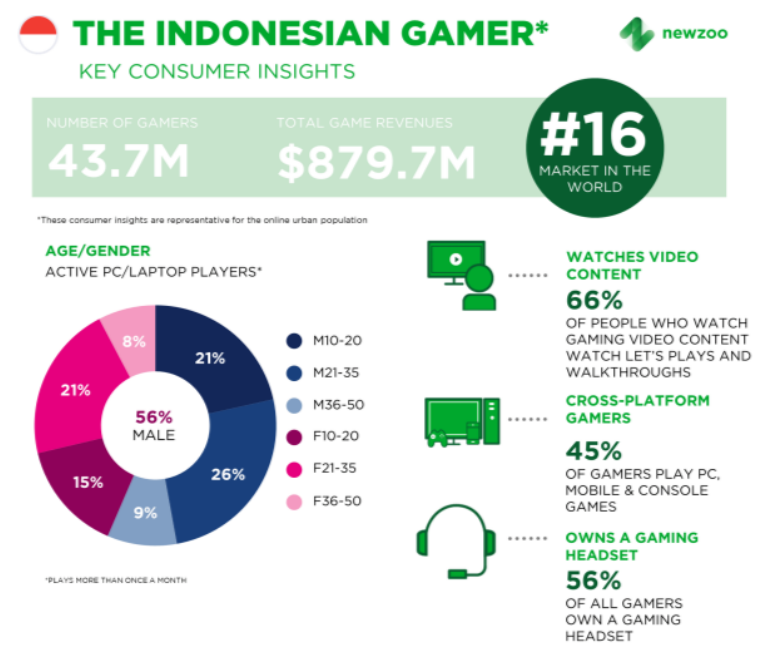

\section{Gambar 1. Data Indonesian Gamer Tahun 2017}

Indonesia merupakan negara peringkat ke 16 sebagai market game dunia. Dari 43,7 juta pemain game di Indonesia tahun 2017, 36\% merupakan pemain game yang berada di usia sekolah (umur 10 - 20 tahun). 21\% merupakan anak laki-laki di usia sekolah dan 15\% merupakan anak perempuan di usia sekolah. 
Game android online memiliki manfaat positif dan dampak negatif. Game android online memiliki manfaat apabila digunakan secara bijak. Manfaat game andoid online antara lain melatih kemampuan otak, mengisi waktu, menghilangkan stress, dan meningkatkan kemampuan Bahasa Inggris. Game android online yang bersifat edukasi mampu meningkatkan kemampuan komunikasi, penalaran, dan disposisi matematika siswa (Bernard, 2015: 221). Game android online apabila dimanfaatkan secara baik mampu meningkatkan penalaran matematika siswa yang masih rendah. Kemampuan penalaran matematika siswa di Indonesia masih rendah ditunjukkan tabel 1.

Tabel 1. Hasil TIMSS 2015

\begin{tabular}{|l|c|c|}
\hline Content Domain & \multicolumn{2}{|l|}{$:$ Numbering } \\
\hline Cognitive Domain & $:$ Reasoning & Peringkat \\
\hline \multicolumn{1}{|c|}{ Nama Negara } & Rerata Nilai & $46 / 49$ \\
\hline Indonesia & 21 & $24 / 49$ \\
\hline Internasional & 58 & $1 / 49$ \\
\hline Finlandia (Tertinggi) & 76 & \\
\hline
\end{tabular}

(Mullis, Martin, Foy, \& Hooper, 2015: 66)

Kemampuan penalaran matematika siswa di Indonesia masih terpaut 37 poin dari rata-rata kemampuan penalaran matematika internasional. Kemampuan penalaran matematika siswa di Indonesia hanya terpaut 3 peringkat dari negara terbawah. Kemampuan penalaran siswa di Indonesia perlu ditingkatkan terutama setelah masuknya level penalaran pada soal ujian nasional. "Reasoning is thinking aimed at reaching true or justifieble conclusions" (Moshman, 2015: 22). Kemampuan penalaran matematika menggambarkan proses berpikir yang memiliki target untuk mencapai kebenaran atau kesimpulan yang benar. "The reasoning skills include the ability to find a mathematical pattern of symptoms, the student's 
ability to make a conjecture, and the student's ability to evaluate the validity of a mathematical argument" (Habsah, 2017: 44). Penalaran matematika digambarkan oleh kemampuan yang meliputi menemukan pola, merumuskan kesimpualan sementara, dan mengevaluasi validitas dari kesimpulan yang dibuat. Dari pendapat tentang penalaran matematika, dapat digeneralisasikan bahwa penalaran matematika merupakan suatu proses berpikir untuk menyelesaikan masalah dengan cara menemukan pola, membuat kesimpulan dan mengevaluasi dugaan. Dalam penelitian ini penalaran matematika ditunjukkan dengan skor yang akan dinilai melalui indikator kemampuan menemukan pola dan kemampuan membuat kesimpulan dalam menentukan barisan dan pola bilangan.

Untuk mengatasi permasalahan rendahnya kemampuan penalaran matematika siswa maka penulis berusaha untuk mengembangkan media pembelajaran berupa game edukasi android Mat Croco yang berorientasi kepada kemampuan penalaran matematika siswa. Media pembelajaran tersebut dikembangkan berdasarkan salah satu teori pengembangan sehingga penulis memproduksi game edukasi android Mat Croco yang memiliki kualitas baik. Game Edukasi Mat Croco merupakan media pembelajaran berupa game android petualangan yang berisi rintanganrintangan berupa barisan aritmetika, barisan geometri, pola bilangan persegi, pola bilangan segitiga dan pola bilangan lainnya. Game edukasi Mat Croco terdiri dari beberapa level yang di dalamnya berisi pola bilangan yang berbeda-beda. Game edukasi Mat Croco diperuntukkan bagi siswa kelas 8 pada pelajaran matematika KD 3.1 "Membuat generalisasi dari pola pada barisan bilangan dan barisan konfigurasi objek". 
Barisan aritmetika merupakan suatu barisan yang diperoleh dengan cara menjumlahkan atau mengurangkan suku sebelumnya dengan suatu bilangan tetap (Marsigit, Susanti, Mahmudi, \& Dhoruri, 2011: 156). Bilangan tetap tersebut disebut beda atau dilambangkan dengan $b$. Sedangkan, barisan geometri merupakan suatu barisan yang diperoleh dengan cara mengalikan suku sebelumnya dengan suatu bilangan tetap (Marsigit, Susanti, Mahmudi, \& Dhoruri, 2011: 159). Bilangan tetap tersebut disebut dengan rasio atau dilambangkan dengan $r$. Pola bilangan segitiga merupakan barisan bilangan yang membentuk pola yang apabila disusun membentuk segitiga sama sisi. Pola bilangan segitiga terdiri dari $1,3,6,10,15,21, \ldots$. Pola bilangan persegi merupakan barisan bilangan yang membentuk pola yang apabila disusun membentuk persegi. Pola bilangan persegi terdiri dari bilangan 1, 4, 9, 16, 25, .... Gambar pola bilangan segitiga dan pola bilangan persegi ditunjukkan gambar 3 dan gambar 4 .
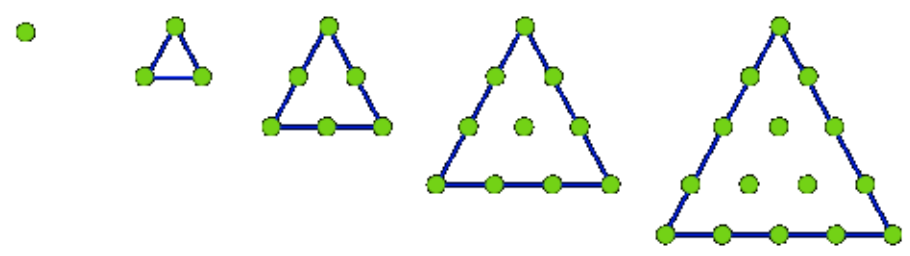

Gambar 3. Pola Bilangan Segitiga
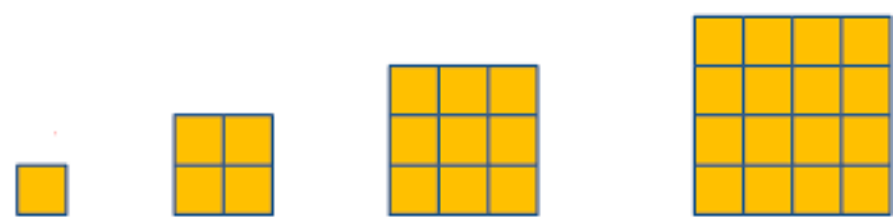

\section{Gambar 4. Pola Bilangan Persegi}


Berdasarkan uraian di atas disimpulkan bahwa game edukasi android Mat Croco merupakan game edukasi platform android yang bertujuan untuk memberikan pengalaman belajar siswa dalam materi barisan aritmetika, barisan geometri, pola bilangan segitiga, pola bilangan persegi dan pola bilangan lainnya. Game edukasi Mat Croco dikembangkan pada mata pelajaran matematika kelas 8 materi barisan dan deret. Tujuan pengembangan game edukasi Mat Croco adalah untuk meningkatkan kemampuan penalaran matematika siswa terutama pada materi barisan bilangan. Sesuai dengan permasalahan, maka tujuan pengembangan game edukasi android Mat Croco ini adalah: mengembangkan game edukasi android Mat Croco yang valid, mengembangkan game edukasi android Mat Croco yang praktis, dan mengembangkan game edukasi android Mat Croco yang dikembangkan efektif berorientasi pada penalaran matematika siswa.

\section{B. Metode}

Metode penelitian ini adalah penelitian pengembangan. Model pengembangan media pembelajaran yang dipilih adalah model pengembangan ADDIE. Model pengembangan ADDIE merupakan model pengembangan yang terdiri dari 5 tahap yaitu: analysis, design, development, implementation, dan evaluation. Tahap-tahap model pengembangan ADDIE ditunjuk gambar 2.

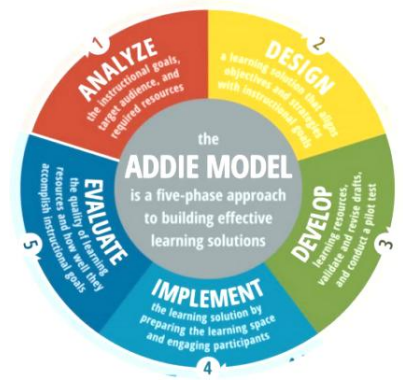

Gambar 2. Tahap Model Pengembangan ADDIE (Branch, 2009: 2) 
Tahap pertama dalam model pengembangan ADDIE adalah tahap analisis. Tahap analisis merupakan tahap mengidentifikasi kemungkinankemungkinan penyebab adanya masalah pada kompetensi siswa. Beberapa prosedur yang dilakukan pada tahap ini adalah menentukan kompetensi siswa yang bermasalah, menentukan tujuan pengembangan, menentukan subjek penelitian pengembangan, menentukan perangkat pengembangan yang dibutuhkan, menentukan sistem pelaksanaan pengembangan dan menyusun rencana-rencana proyek pengembangan.

Tahap kedua model pengembangan ADDIE adalah tahap perancangan. Tahap kedua ini merupakan tahap menentukan solusi dan strategi yang mungkin dilaksanakan untuk mencapai tujuan penelitian pengembangan. Prosedur-prosedur yang dilaksanakan pada tahap perancangan adalah menginventasisasi hal-hal yang akan dilakukan pada saat penelitian pengembangan, menyusun tujuan-tujuan tahap pengembangan, menyimpulkan strategi dan media yang akan dikembangkan, dan menghitung manfaat-manfaat yang diperoleh dari penelitian pengembangan tersebut. Produk yang dihasilkan tahap perancangan adalah desain karya.

Tahap ketiga model pengembangan ADDIE adalah tahap pengembangan. Tahap pengembangan merupakan tahap mengembangkan strategi atau media yang dikembangkan serta menyusun tes yang digunakan untuk menguji keberhasilan pengembangan tersebut. Prosedur yang dilaksanakan pada tahap ketiga ini adalah mengembangkan konten, mengembangkan media pendukung, mengembangkan cara penggunaan bagi guru dan siswa, memvalidasi konten, merevisi konten serta mengembangkan draf akhir atau pilot project yang akan diimplementasikan kepada subjek penelitian. Produk yang 
dihasilkan tahap perancangan adalah draf 1 , draf 2 dan draf 3 (draf akhir atau pilot project).

Tahap keempat model pengembangan ADDIE adalah tahap implementasi. Tahap implementasi merupakan tahap mempersiapkan lingkungan belajar sehingga siswa dapat terlibat dalam implementasi pengembangan. Prosedur pada tahap implementasi adalah mempersiapkan guru dan siswa untuk pembelajaran dan melaksanakan pembelajaran yang berkaitan dengan penelitian pengembangan. Tahap terakhir pada model pengembangan ADDIE adalah tahap evaluasi. Tahap ini merupakan tahap menilai kualitas produk yang dikembangkan dan membandingkan ketercapaian kompetensi siswa antara sebelum dan setelah implementasi pengembangan. Prosedur pada tahap ini adalah menentukan kriteria keberhasilan pengembangan, menentukan alat evaluasi, dan melaksanakan evaluasi.

Pengembangan media pembelajaran harus menghasilkan media pembelajaran yang berkualitas. Pengembangan media pembelajaran dapat dilakukan melalui penelitian pengembangan agar dapat dihasilkan produk valid, praktis dan efektif. Media pembelajaran yang baik kualitasnya harus memiliki kriteria kevalidan, kepraktisan, dan keefektivan (Musfiqi \& Jailani, 2014: 49).

a. Kevalidan

"The components of the material should be bassed on state-of-the art knowledge (content validity), and all componeents should be based onconsistently linked to each other (construct validity) (Nieveen, 1999: 127). Suatu produk pengembangan berkriteria valid jika komponen yang melandasi pembuatan produk harus sesuai (validitas isi). Produk yang dikembangkan selaras dengan kompetensi dasar, materi dan tujuan 
pembelajaran. Komponen dari produk tersebut juga harus saling terkait (validitas konstruk). Kevalidan terdiri dari tiga kriteria: (1) kelayakan materi; (2) kelayakan ilustrasi; dan (3) kelayakan tampilan. Jika produk inovasi pembelajaran oleh expert dinyatakan memenuhi tiga kriteria tersebut, maka media pembelajaran dinyatakan valid.

b. Kepraktisan

Nieveen (1999: 127) mengatakan bahwa "...is that teachers (and, other experts) consider the materials to be usable and that it is easy for teachers, and students to use the materials". Suatu produk pengembangan dikatakan praktis dilihat dari kemudahan produk yang dikembangkan untuk dipakai guru dan siswa. Kepraktisan terdiri atas dua kriteria: (1) media pembelajaran mudah dan sederhana digunakan oleh guru; dan (2) media pembelajaran mudah dan sederhana digunakan oleh siswa. Jika media pembelajaran dinilai dapat diterapkan serta mudah sederhana digunakan oleh guru dan siswa, maka media pembelajaran dinyatakan praktis.

Analisis uji kevalidan dan uji kepraktisan diawali dengan data kuantitatif akan dikualitatifkan dengan skala lima. Adapun kriteria atau parameter kevalidan dan kepraktisan ditunjukkan tabel berikut.

\section{Tabel 2. Kriteria Kevalidan dan Kepraktisan}

\begin{tabular}{|c|c|}
\hline Selang Skor & Kategori \\
\hline$X>\bar{X}_{i}+1,8$ Sbi & Sangat Baik, \\
\hline $\bar{X}_{i}+0,6 \mathrm{Sbi} i X \leq \bar{X}_{i}+1,8 \mathrm{Sbi}$ & Baik, \\
\hline $\bar{X}_{i}-0,6 \mathrm{Sbi} i<\leq \bar{X}_{i}+0,6 \mathrm{Sbi}$ & Cukup, \\
\hline $\bar{X}_{i}-1,8 \mathrm{Sbi} i \bar{X}_{i} \leq \bar{X}_{i}-0,6 \mathrm{Sbi}$ & Kurang Baik, \\
\hline$X \leq \bar{X}_{i}-1,8 \mathrm{Sbi}$ & Sangat Kurang Baik \\
\hline
\end{tabular}

(Widoyoko, 2012) 
Lambang $\bar{X}_{i}$ merupakan rerata ideal. Sbi merupakan simpangan baku ideal dan $X$ merupakan skor empiris. Rerata ideal didapat dari setengah jumlah skor maksimal ideal dan skor minimum ideal. Simpangan baku ideal diperoleh dari seperenam selisih skor maksimal ideal dan skor minimal ideal.

c. Keefektifan

(Nieveen, 1999:127) mengatakan bahwa "...is that students appreciate the learning program and that desired learning takes place.". Produk pengembangan disebut efektif apabila dalam penggunaannya produk pengembangan tersebut memberikan hasil pembelajaran yang selaras dengan harapan. Keefektifan media pembelajaran dinilai dari seberapa mampu meningkatkan kompetensi siswa. Jika media pembelajaran mampu membantu guru meningkatkan kompetensi siswa secara signifikan maka media pembelajaran dinyatakan efektif.

Berdasarkan beberapa pendapat di atas maka dapat disimpulkan bahwa model pengembangan yang digunakan pada penelitian ini adalah model pengembangan ADDIE. Tahap-tahap model pengembangan ADDIE adalah analysis, design, development, implementation, dan evaluation. Model pengembangan ADDIE dipilih karena sesuai dengan pengembangan media pembelajaran yang dilaksanakan di sekolah. Untuk menguji kualitas hasil model pengembangan dilaksanakan uji kevalidan, uji kepraktisan dan uji keefektifan.

\section{Hasil dan Pembahasan}

Tahap pertama pengembangan ini adalah tahap analisis. Game edukasi android Mat Croco ini terinspirasi dari belum banyaknya media pembelajaran matematika materi barisan dan deret yang bersifat digital 
serta banyaknya siswa yang memainkan game android (seperti PUGB, Mobile Legend, MineCraft dan lainnya) sebagai dampak dari revolusi industri 4.0. Game edukasi android Mat Croco dengan mudah dapat diinstal di ponsel siswa karena hanya membutuhkan kapasitas 50mb. Game edukasi android Mat Croco akan dikembangkan bertujuan untuk menjadi solusi 2 hal yaitu mengurangi kecanduan siswa akan game android yang kurang berguna dan sebagai alternatif pembelajaran matematika yang inovatif pada materi barisan dan deret.

Desain karya game edukasi android Mat Croco merupakan produk tahap perancangan. Desain rancang media pembelajaran game edukasi android Mat Croco versi 1.0 terdiri dari 8 layout. Desain karya game edukasi android Mat Croco dapat ditunjukkan gambar 6.

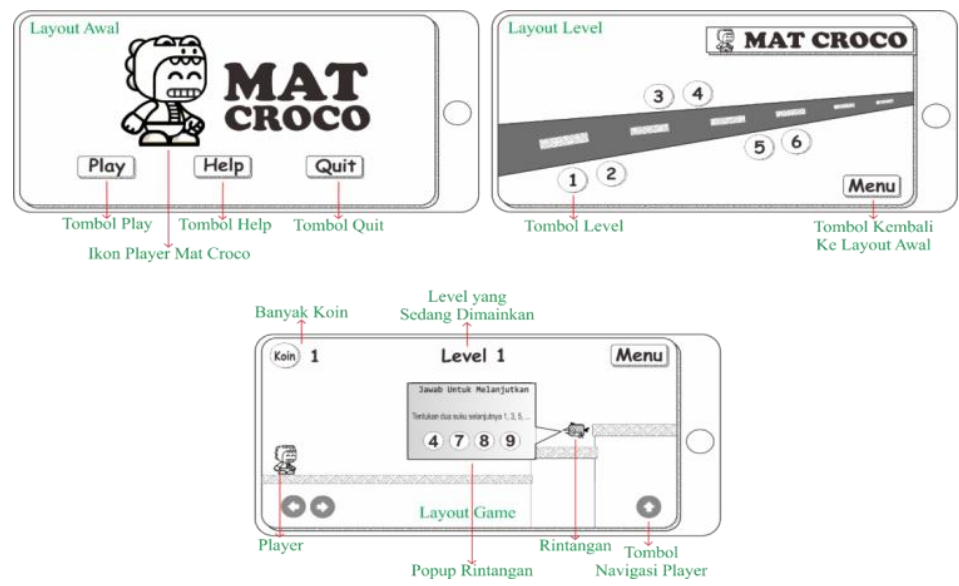

Gambar 6. Desain Karya Game Edukasi Android Mat Croco

Desain karya game edukasi android Mat Croco terdiri dari beberapa layout. Layout pertama adalah layout awal yang berisi tombol play, help dan quit. Pada layout awal juga berisi petunjuk cara bermain game edukasi android Mat Croco dengan menyentuh tombol help. Layout 
kedua dalam game edukasi ini adalah layout level. Layout level adalah jalan menuju masing-masing level game. Dalam layout level terdapat tombol level yang terdiri dari angka-angka yang akan membawa pemain ke level sesuai angka yang tertera. Layout selanjutnya terdiri dari 6 layout game. Dalam setiap layout game terdapat player, rintangan, popup rintangan, dan koin. Pada level 1 dan 2 apabila player bertemu dengan rintangan, akan memunculkan popup yang berisi barisan aritmetika. Pada level 3 dan 4 rintangan akan memunculkan popup barisan geometri. Pada level 5 akan memunculkan popup pola bilangan persegi dan segitiga. Sedangkan pada level 6 akan memunculkan popup pola bilangan bebas. Semakin tinggi level yang mainkan maka pola bilangan yang ada semakin sulit dipecahkan.

Pola bilangan yang ada pada game edukasi android Mat Croco bertujuan untuk meningkatkan penalaran matematika siswa sehingga mampu menentukan pola dan membuat generalisasi tentang barisan atau pola bilangan. Definisi operasional dari variable-variabel penelitian pengembangan ini adalah: (1) Game edukasi android Mat Croco merupakan game edukasi yang akan dimainkan siswa pada ponsel masing-masing dan berisi popup-popup barisan aritmetika, barisan geometri, pola bilangan segitiga, pola bilangan persegi serta pola bilangan lainnya; dan (2) Penalaran matematika ditunjukkan dengan skor yang akan dinilai melalui indikator kemampuan menemukan pola dan kemampuan membuat kesimpulan dalam menentukan barisan dan pola bilangan.

Setelah tahap perancangan dilaksanakan, tahap selanjutnya adalah tahap pengembangan. Produk pertama yang dihasilkan pada tahap ini adalah draft 1 game edukasi android Mat Croco. Draft 1 game edukasi 
android Mat Croco merupakan realisasi dari desain karya pada tahap perancangan yang ditunjukkan gambar 6. Pembuatan game edukasi android Mat Croco menggunakan software Construct 2. Hasil dari Construct 2, game edukasi android Mat Croco bisa dieksport ke format html 5. Format html 5 kemudian dieksport menjadi *.apk menggunakan software Web2Apk. Apk yang dihasilkan berkapasitas $52 \mathrm{Mb}$ yang nantinya dapat diinstal di ponsel berplatform android. Rancangan awal atau draf 1 game edukasi android Mat Croco setelah diinstal di android ditunjukkan oleh gambar 7 dan gambar 8 .

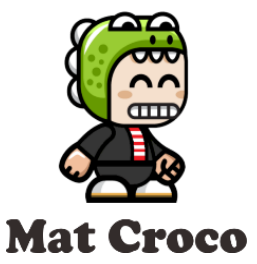

Gambar 7: Ikon Mat Croco di Ponsel Android

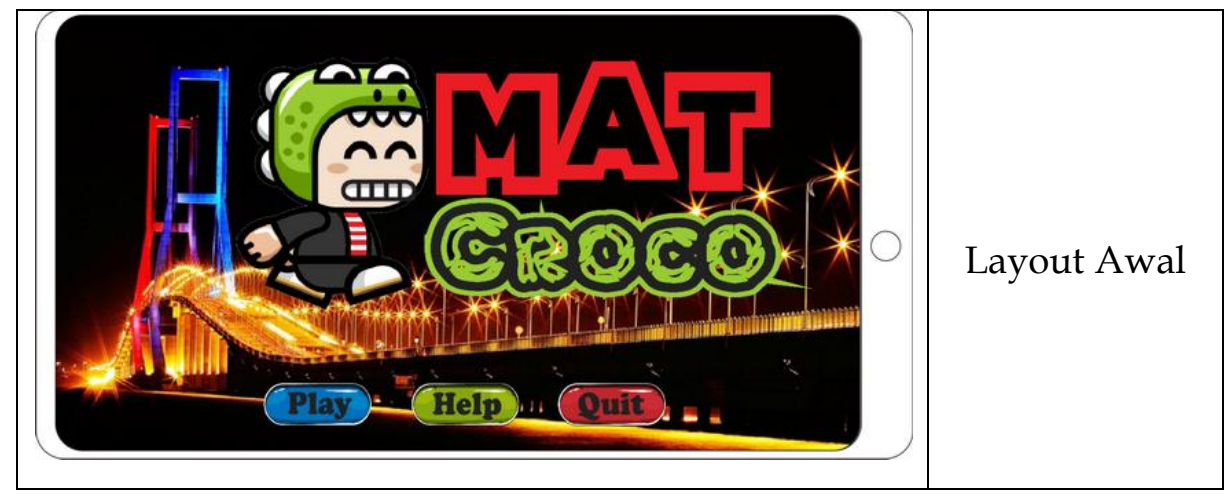




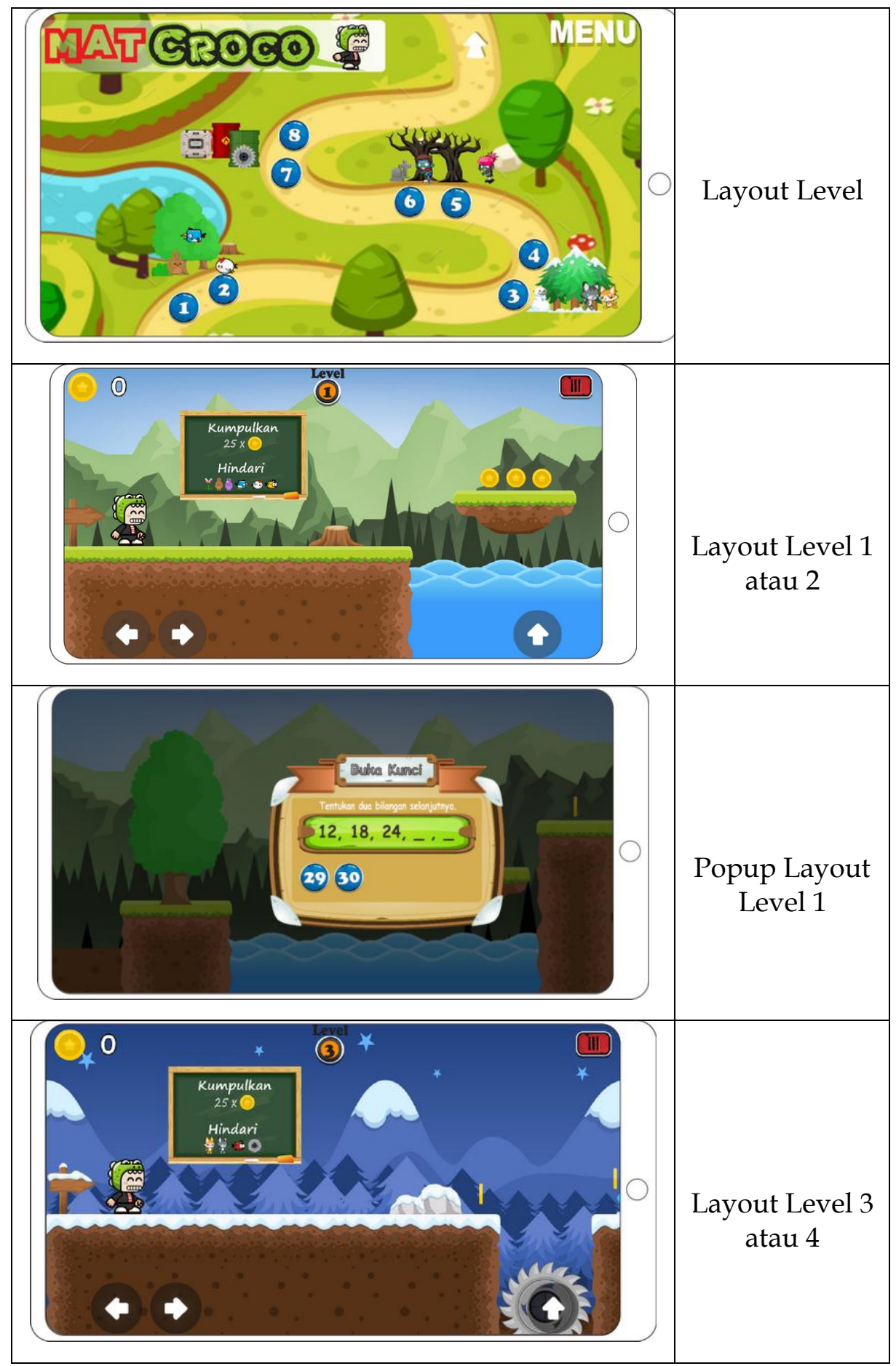


Gambar 8: Layout Draf 1 (Prototype) Game Edukasi Android Mat Croco

Cara bermain game edukasi android Mat Croco adalah sama dengan bermain game android petualangan pada umumnya. Player diminta untuk mengumpulkan 25 koin pada setiap level. Pada setiap level disediakan rintangan yang berbeda-beda. Apabila player bertemu atau menyentuh rintangan maka popup masing-masing rintangan akan muncul. Player harus memecahkan popup yang muncul untuk melanjutkan permainan. Popup yang muncul berisi barisan atau pola bilangan yang berbeda di setiap level. Pada level 1 popup berisi barisan aritmetika dengan beda bilangan positif. Popup level 2 berisi barisan aritmetika dengan beda bilangan negatif. Pada level 3 popup berisi barisan geometri dengan rasio bilangan bulat. Pada level 4 popup berisi barisan geometri dengan rasio pecahan. Pada level 5 popup berisi pola bilangan persegi dan segitiga. Pada level 6 popup berisi pola bilangan lainnya. Player diminta mencari dua suku selanjutnya dari barisan atau pola bilangan tersebut. Apabila player salah dalam memecahkan popup, layout akan dimulai dari awal dan koin yang dikumpulkan akan dimulai dari 0. Draf 1 game edukasi android Mat Croco dilakukan uji validitas oleh Bapak Bukhori, M.Pd (Dosen Matematika STAIDA Muhammadiyah Garut) dan Bapak Aji Wibowo, M.Pd (Guru matematika yang memiliki tesis tentang penalaran matematika). Hasil uji validasi oleh dua orang ahli ditunjukkan pada gambar 9 berikut. 


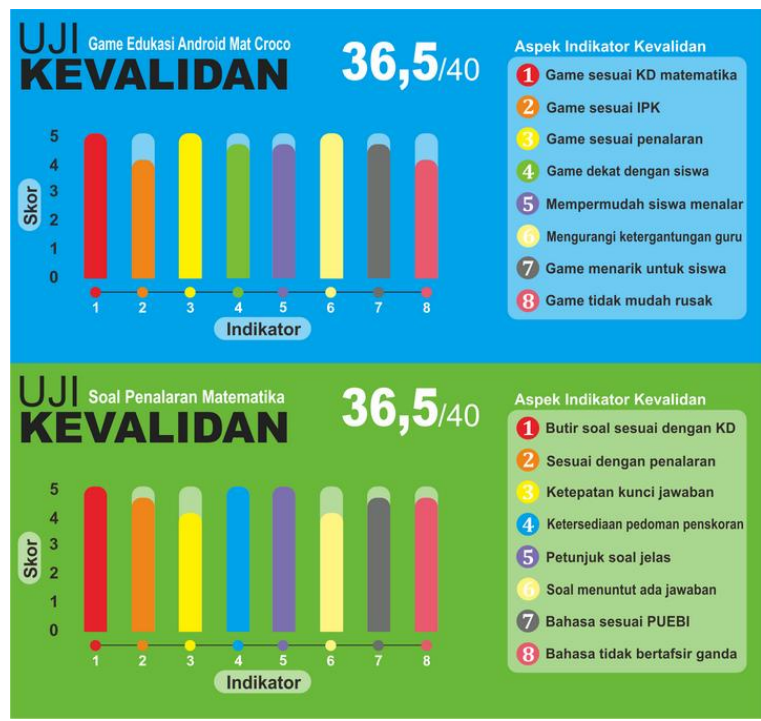

\section{Gambar 9. Hasil Uji Validasi Game Edukasi Android Mat Croco}

Kriteria validasi dan kepraktisan game edukasi android Mat Croco sebagai berikut.

Skor maksimal ideal $=8$ (butir aspek) $\times 5$ (skor maksimal $)=40$

Skor minimal ideal $=8($ butir aspek) $\times 1($ skor minimal $)=8$

$$
\bar{X}_{i}=\frac{40+8}{2}=\frac{48}{2}=24 \quad S b i=\frac{40-8}{6}=\frac{32}{6}=5,33
$$

Tabel 3. Kriteria Kevalidan dan Kepraktisan Game Edukasi Android Mat Croco

\begin{tabular}{|c|c|}
\hline Selang Skor & Kategori \\
\hline$X>33,6$ & Sangat Baik, \\
\hline $27,2<X \leq 33,6$ & Baik, \\
\hline $20,8<X \leq 27,2$ & Cukup, \\
\hline $14,4<X \leq 20,8$ & Kurang Baik, \\
\hline$X \leq 14,4$ & Sangat Kurang Baik \\
\hline
\end{tabular}


Berdasarkan gambar 9 jumlah skor uji kevalidan sama-sama 36,5. Berdasarkan tabel 3, game edukasi android Mat Croco memiliki validitas yang sangat baik. Kedua validator berkesimpulan bahwa game edukasi android Mat Croco dapat digunakan tanpa perbaikan. Berdasarkan gambar 9, soal penalaran matematika telah layak digunakan untuk mengukur penalaran matematika dengan sedikit perbaikan. Perbaikan soal penalaran matematika hanya terbatas perbaikan yang bersifat redaksional. Karena hasil uji validasi game edukasi android Mat Croco disimpulkan dapat digunakan tanpa perbaikan maka draf 1 game edukasi android Mat Croco naik menjadi draf (prototype) 2 yang diuji kepraktisan.

Untuk mengetahui kepraktisan, game edukasi android Mat Croco dilakukan uji kepraktisan atau simulasi game edukasi android Mat Croco oleh guru dan siswa. Uji kepraktisan dilakukan oleh dua orang guru matematika SMPN 1 Tanahmerah yaitu Ibu Husnul Hotimah, S.Pd dan Ibu Siti Yuliatur Rosidah, S.Si. Uji kepraktisan juga dinilai oleh dua siswa. Hasil uji kepraktisan oleh guru dan siswa ditunjukkan oleh gambar 10.

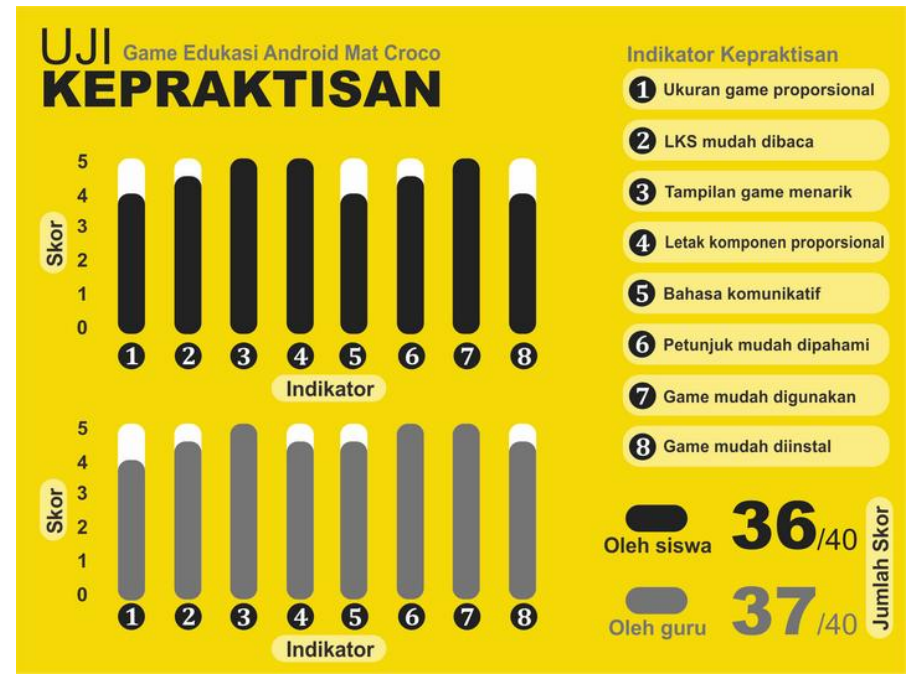

Gambar 10: Hasil Uji Kepraktisan Game Edukasi Android Mat Croco 
Gambar 10 menunjukkan bahwa jumlah skor uji kepraktisan yang dilakukan oleh siswa adalah 36. Berdasarkan tabel 3, game edukasi android Mat Croco dinilai oleh guru memiliki kepraktisan yang sangat baik. Gambar 10 menunjukkan bahwa jumlah skor uji kepraktisan yang dilakukan oleh guru adalah 37. Game edukasi android Mat Croco juga termasuk kategori memiliki kepraktisan yang sangat baik berdasarkan penilaian oleh siswa. Berdasarkan uji kepraktisan yang dilaksanakan oleh 2 guru dan 2 siswa, dapat ditarik simpulan bahwa game edukasi android Mat Croco memiliki kepraktisan yang sangat baik. Karena game edukasi android Mat Croco memiliki kepraktisan yang sangat baik, draf 2 game edukasi android Mat Croco statusnya menjadi draf akhir atau pilot project game edukasi android Mat Croco.

Data aplikasi praktis game edukasi android Mat Croco di kelas 8A SMPN 1 Tanahmerah berupa data penalaran matematika siswa kelas 8A SMPN 1 Tanahmerah. Data tersebut diperoleh dengan tes uraian yang dilaksanakan selama 60 menit. Tes dilaksanakan sebelum (pretes) dan sesudah (postes) pembelajaran dengan menggunakan game edukasi android Mat Croco. Hasil aplikasi praktis game edukasi android Mat Croco di kelas 8A SMPN 1 Tanahmerah ditunjukkan gambar 13 berikut.

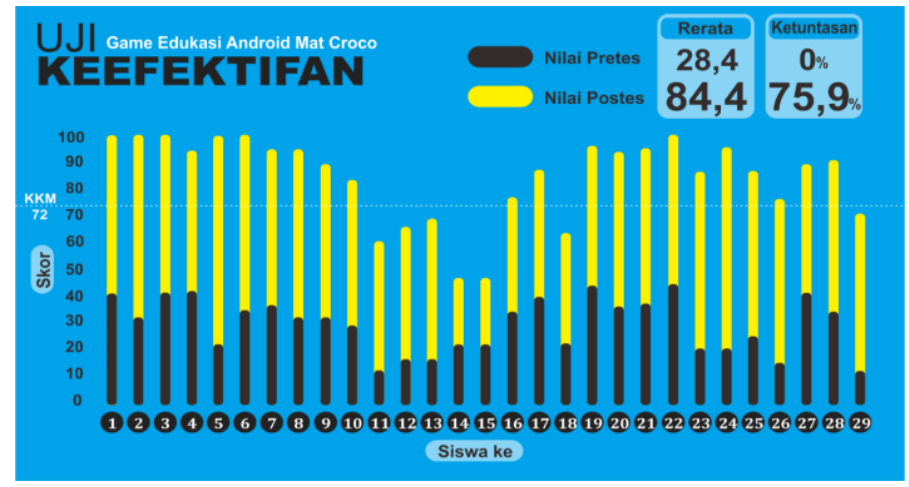

Gambar 13: Hasil Aplikasi Praktis Game Edukasi Android Mat Croco 
Analisis data hasil implementasi (aplikasi) game edukasi android Mat Croco dilaksanakan menggunakan analisis deskriptif dan analisis statistik inferensial. Analisis deskriptif menggunakan analisis peningkatan rata-rata nilai penalaran matematika dan peningkatan persentase ketuntasan klasikal. Rata-rata nilai penalaran matematika dan persentase (\%) ketuntasan klasikal ditunjukkan oleh gambar 13 menunjukkan peningkatan. Rata-rata nilai penalaran matematika meningkat dari 28,4 pada pretest menjadi 84,4 pada posttest. Ketuntasan klasikal meningkat dari $0 \%$ siswa yang tuntas pada pretest menjadi $75,9 \%$ siswa yang tuntas pada posttest. Kriteria ketuntasan minimal yang digunakan adalah kriteria ketuntasan minimal yang digunakan SMPN 1 Tanahmerah sebesar 72 .

Analisis data hasil aplikasi praktis game edukasi android Mat Croco juga dilaksanakan secara statistik inferensial. Uji yang digunakan adalah uji asumsi dan uji hipotesis. Uji asumsi hasil implementas atau aplikasi praktis game edukasi android Mat Croco dilaksanakan dua uji yaitu uji normalitas dan uji homogenitas. Kedua uji asumsi ini dianalisis dengan program SPSS. Hipotesis uji normalitas adalah:

$\mathrm{H}_{0} \quad$ : Kelas 8A berasal dari populasi yang berdistribusi normal $\mathrm{H}_{1} \quad$ : Kelas $8 \mathrm{~A}$ berasal dari populasi yang tidak berdistribusi normal

Uji normalitas menggunakan Kolmogorov-Smirnov Test menggunakan SPSS yang hasilnya pada tabel 4 . 
Tabel 4: Hasil Uji Normalitas dengan SPSS (Kolmogorov-Smirnov Test) One-Sample Kolmogorov-Smirnov Test

\begin{tabular}{llr} 
& & \multicolumn{1}{c}{ Nilai } \\
\hline $\mathrm{N}$ & & 29 \\
\hline Normal Parametersa,b & Mean & 28.4621 \\
\cline { 2 - 3 } & $\begin{array}{l}\text { Std. } \\
\text { Deviation }\end{array}$ & 12.23205 \\
\hline Most Extreme & Absolute & .123 \\
\cline { 2 - 3 } Differences & Positive & .123 \\
\cline { 2 - 3 } & Negative & -.115 \\
\hline Test Statistic & & .123 \\
\hline Asymp. Sig. (2-tailed) & & $.200^{c, d}$ \\
\hline
\end{tabular}

a. Test distribution is Normal.

b. Calculated from data.

c. Lilliefors Significance Correction.

$\mathrm{d}$. This is a lower bound of the true significance.

Tabel 4 menunjukkan bahwa sig. $>0,05(0,2>0,05)$ sehingga $\mathrm{H}_{0}$ diterima. Kelas 8A SMPN 1 Tanahmerah berasal dari populasi berdistribusi normal. Uji asumsi yang kedua adalah uji homogenitas. Hipotesis uji homogenitas adalah:

$\mathrm{H}_{0}: \sigma_{1}^{2}=\sigma_{2}^{2} \quad$ Varian nilai sebelum (pretes) dan sesudah (postes) menggunakan game edukasi android Mat Croco homogen

$\mathrm{H}_{1}$ : $\quad$ Varian nilai sebelum (pretes) dan sesudah (postes) $\sigma_{1}^{2} \neq \sigma_{2}^{2} \quad$ menggunakan game edukasi android Mat Croco tidak homogen

Uji homogenitas menggunakan Test of Homogeneity of Variances menggunakan SPSS yang hasilnya pada tabel 5 . 
Tabel 5: Hasil Uji Homogenitas dengan SPSS (Test of Homogeneity of Variances)

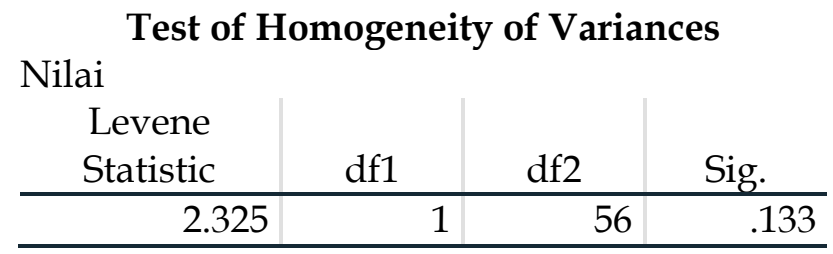

Tabel 5 menunjukkan bahwa nilai W (Lavene Statistic) adalah 2,325 dan nilai sig. 0,133 . Karena nilai $W(2,325)<$ nilai $F$ tabel $\left(F_{0,05 ; 1 ; 56}=4,013\right)$ dan sig. $(0,133)>0,05$ maka $\mathrm{H}_{0}$ diterima sehingga Varian nilai sebelum (pretes) dan sesudah (postes) menggunakan game edukasi android Mat Croco homogen. Berdasarkan uji normalitas \& uji homogenitas dinyatakan bahwa sampel (Kelas $8 \mathrm{~A}$ ) datang dari populasi berdistribusi normal dan varian nilai sebelum (pretes) dan sesudah (postes) menggunakan game edukasi android Mat Croco homogen sehingga memenuhi asumsi untuk dilanjutkan ke uji hipotesis.

Sebelum uji hipotesis maka perlu dirumuskan hipotesis uji keefektifan penggunaan media pembelajaran game edukasi android Mat Croco terhadap penalaran matematika. Hipotesis penelitian ini adalah:

$\mathrm{H}_{0}: \delta_{2} \leq \delta_{1} \quad$ Penalaran matematika siswa sesudah penggunaan game edukasi android Mat Croco tidak lebih baik dari pada penalaran matematika siswa sebelum menggunakan game edukasi android Mat Croco

$\mathrm{H}_{1}: \delta_{2}>\delta_{1} \quad$ Penalaran matematika siswa sesudah penggunaan game edukasi android Mat Croco lebih baik dari pada penalaran matematika siswa sebelum menggunakan game edukasi android Mat Croco

Uji hipotesis ini menggunakan Paired Samples Test menggunakan SPSS yang hasilnya pada tabel 6. 
Tabel 6. Hasil Uji Keefektifan Menggunakan SPSS (Paired Samples Test)

Paired Samples Test

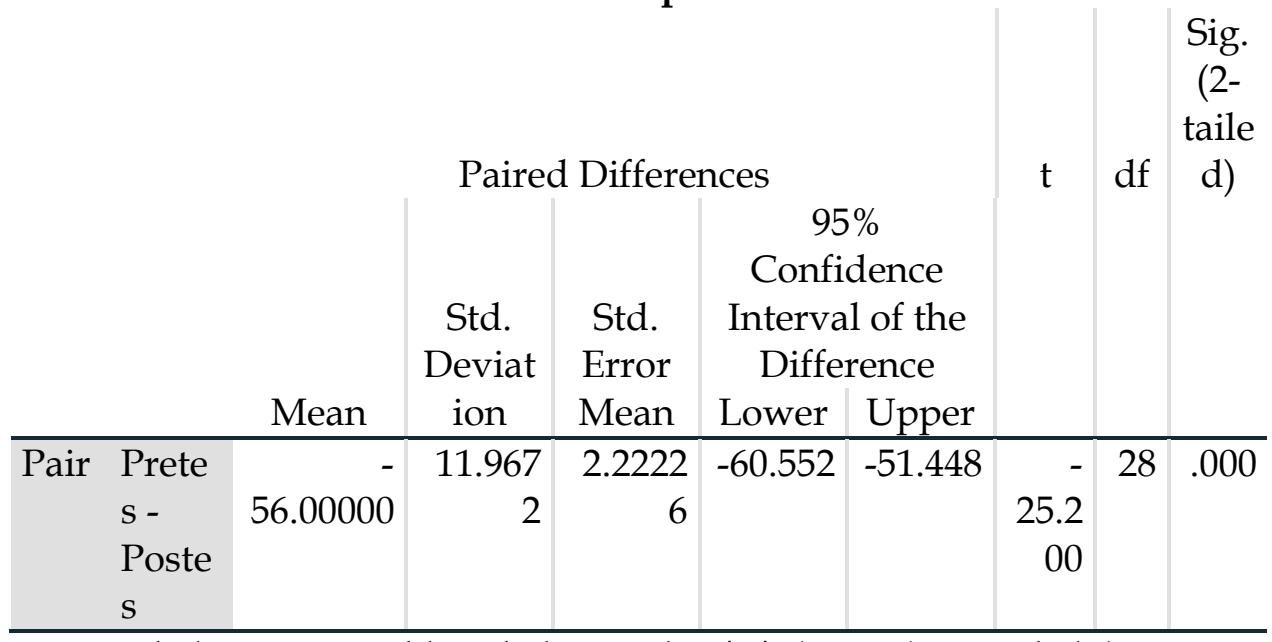

Tabel 6 menunjukkan bahwa nilai $|\mathrm{t}|(25,200)>\mathrm{t}$ tabel $\left(\mathrm{t}_{0,025 ; 28}=\right.$ 2,368) dan sig. $(0,000)<0,025$ sehingga $\mathrm{H}_{0}$ ditolak atau $\mathrm{H}_{1}$ diterima. Hal ini menunjukkan bahwa penalaran matematika siswa sesudah pembelajaran menggunakan game edukasi android Mat Croco lebih baik dari pada penalaran matematika siswa sebelum menggunakan game edukasi android Mat Croco. Keefektifan game edukasi android Mat Croco terhadap penalaran matematika juga dapat dilihat dari isian LKS. Isian LKS menunjukkan bahwa sebanyak $83,10 \%$ siswa mampu menunjukkan penalaran matematika melalui isian LKS yang mempresentasikan indikator penalaran matematika.

Berdasarkan analisis data secara deskriptif dan analisis data secara statistik inferensial, dapat disimpulan bahwa game edukasi android Mat Croco efektif untuk meningkatkan penalaran matematika siswa. Game edukasi android Mat Croco yang menarik mampu meningkatkan ketertarikan siswa dan membuat siswa lebih berkonsentrasi terhadap kegiatan pembelajaran. 


\section{Penutup}

Media pembelajaran game edukasi android Mat Croco dikembangkan berdasarkan model ADDIE yang memiliki tahapantahapan analysis, design, development, implementation, dan evaluation. Berdasarkan tahapan-tahapan pengembangan game edukasi android Mat Croco dapat dibuat simpulan bahwa game edukasi android Mat Croco baik kualitasnya dan dapat diaplikasikan dalam pembelajaran matematika kelas 8 materi barisan dan deret. Hal ini didasarkan bahwa game edukasi android Mat Croco memiliki kevalidan yang baik. Hal ini dibuktikan dengan pengujian kevalidan yang dilakukan oleh dua orang ahli, yaitu ahli media pembelajaran dan ahli penalaran matematika. Game edukasi android Mat Croco memiliki kepraktisan yang sangat baik. Game edukasi android Mat Croco memiliki kepraktisan yang sangat baik setelah dilakukan pengujian kepraktisan oleh dua orang guru matematika dan dua orang siswa; dan Game edukasi android Mat Croco efektif meningkatkan penalaran matematika siswa. Hal ini setelah dilakukan pengujian keefektifan menggunakan analisis data secara deskriptif dan analisis statistik inferensial.

\section{Ucapan Terima Kasih}

Terima kasih saya sampaikan kepada Bapak Kepala Sekolah dan temanteman guru di SMP Negeri 1 Tanahmerah, Bangkalan, Madura yang telah memberikan fasilitas dan bantuan sehingga penelitian tindakan kelas dan penulisan artikel ini dapat diselesaikan dengan baik.

\section{Daftar Pustaka}

Arsyad, A. (2013). Media Pembelajaran. Jakarta: PT. Raja Graafindo Persada. 
Bernard, M. (2015). Meningkatkan Kemampuan Komunikasi dan Penalaran serta Disposisi Matematika Siswa SMK dengan Pendekatan Kontekstual melalui Game Adobe Flash CS 4.0. Infinity, 4(2), 197-222.

Branch, R. M. (2009). Intructional Design: The ADDIE Approach. London: Springer.

Habsah, F. (2017). Developing Teaching Material Based on Realistic Mathematics Andoriented to the Mathematical Reasoning and Mathematical Communication. Jurnal Riset Pendidikan Matematika, 4(1), 43-55.

Marsigit, Susanti, M., Mahmudi, A., \& Dhoruri, A. (2011). Matematika 3 untuk SMP/MTs Kelas IX. Jakarta: Puskurbuk Kemendiknas.

Moshman, D. (2015). Epistemic Cognition and Development:The Psychology of Justification and Truth. New York: Psychology Press.

Mullis, I. V., Martin, M. O., Foy, P., \& Hooper, M. (2015). TIMSS 2015 International Results in Mathematics. Boston: IEA.

Musfiqi, S., \& Jailani. (2014). Pengembangan Bahan Ajar Matematika yang Berorientasi pada Karakter dan Higher Order Thinking Skill (HOTS). PYTHAGORAS: Jurnal Pendidikan Matematika, 9(1), 45-59.

NCTM. (2000). Principles and standards for school mathematics. Virginia: The National Council of Teachers of Mathematics, Inc.

Newzoo. (2017, Juni 1). The Indonesian Gamer 2017. Dipetik April 10, 2019, dari Newzoo: www.newzoo.com

Nieveen, N. (1999). Prototyping to reach product quality. Design Appoaches and Tools In Education and Training. New York: Springer.

Pratama, U. N., \& Haryanto. (2017). Pengembangan Game Edukasi Berbasis Android tentang Domain Teknologi Pendidikan. Jurnal Inovasi Teknologi Pendidikan UNY, 4(2), 167-184.

Tabrani ZA. (2012a). Future Life of Islamic Education in Indonesia. International Journal of Democracy, 18(2), 271-284.

Tabrani ZA. (2013a). Modernisasi Pengembangan Pendidikan Islam (Suatu Telaah Epistemologi Pendidikan). Serambi Tarbawi, 1(1), 6584 . 
Tabrani ZA. (2013b). Kebijakan Pemerintah dalam Pengelolaan Satuan Pendidikan Keagamaan Islam (Tantangan Terhadap Implementasi Manajemen Berbasis Sekolah). Serambi Tarbawi, 1(2), 65-84.

Widoyoko, E. P. (2012). Teknik Penyusunan Instrumen Penelitian. Yogyakarta: Pustaka Pelajar. 